\title{
Barranca del Cobre: North America's Other Majestic Canyon
}

\author{
by \\ Jeffirey Smith* \\ Photographls by author
}

\section{Introduction}

As one of the world's leading tourist destinations, Mexico appeals to vacationers for a variety of reasons. Some places such as Cancún, Puerto Vallarta, Mazatlán, and Cabo San Lucas are among a long list of sunsoaked coastal locations that stand out for their natural beauty including sandy beaches and crashing surf. Other locations in Mexico such as the Pre-Columbian pyramids near present day Mexico City or the countless Mayan ruins that dot the Yucatan Peninsula offer examples of remarkable human engineering. Still other Mexican destinations attract tourists because of their lengthy human history steeped in rich cultural traditions. Cities throughout the cental highlands including Zacatecas, Guanajuato, San Miguel de Allende and Querétaro showcase ornate, intricately carved, colonial architecture and a cultural landscape that reflects the past.

There is another place in Mexico, however, where all of these elements come together and the juxtaposition of 1) natural beauty, 2) a human engineering marvel, and 3) an unique culture create what many agree is a truly exceptional place. Located approximately 115 miles (186 kilometers) southwest of the city of Chihuahua in northwest Mexico is the often overlooked Barranca del Cobre (more commonly known in English as Copper Canyon). As author Joe Cummings (1998) writes, Copper Canyon is one of Mexico's premier attractions, yet remarkably few foreigners seem to have heard of it. This article highlights some of the reasons why, largely by word-of-mouth, North America's other majestic canyon is gaining popularity as a tourist destination. Barranca del Cobre National Park affords visitors the rare opportunity to take in aweinspiring natural scenery that rivals Arizona's Grand Canyon, ride on the Chihuahua - Pacific Railroad, which is an engineering marvel on par with the Colorado River's great dams projects, and experience an endemic, indigenous culture that both time and the Mexican government seem to have forgotten.

\section{Barranca del Cobre}

Tucked away in the heart of Mexico's Sierra Madre Occidental mountain range, Copper Canyon is seven times larger in surface area, and in places deeper, than Arizona's Grand Canyon. ${ }^{1}$ But such relative comparisons mask the fact that the Copper Canyon region (also referred to locally as Sierra Tarahumara) is actually comprised of over 20 individual canyons including the six primary canyons of Urique, Sinforosa, Batopilas, Septentrión, Candemeña, and del Cobre/Copper (Figure 1).

Overall the Copper Canyon system covers more than 25,000 square miles (64,000 square kilometers) and is dissected by six major rivers with numerous tributaries that eventually converge to form the Rio Fuerte, which flows into the Sea of Cortez. Over the millennia these rivers have carved through the thick (ca. 1,500 feet / 450 meters) uplifted volcanic cap exposing an even thicker layer of folded sedimentary rock that was deposited more than 100 million years ago (Pennington 1963). Incising and mass erosion has created magnificent, plunging chasms accented by gushing waterfalls, including both Piedra Volada and Cascada de

1 The largest and most impressive of the six major canyons is Urique Canyon yawning to a depth of 6,140 feet $(1,870$ meters) making it 105 feet (32 meters) deeper than Arizona's Grand Canyon. However, it should be noted that the Grand Canyon is noticeably wider than any of the individual canyons, and its average depth is deeper than the average depth of the Copper Canyon sistem.
Basaseáchic Mexico's two highest waterfalls. The region is a geomorphologist's delight.

Nearly all of the region's precipitation (ca. $75 \%$ ) comes between late July and midSeptember when the summer monsoon with its towering thunderheads, bolts of lightning, and sheets of rain typically dump up to 45 inches (114 centimeters) of moisture annually. The afternoon storms help settle the dust and transform an otherwise arid land into a lush landscape with abundant, vibrant-green vegetation. Due to orographic processes, more precipitation falls on the uplands than in the canyon bottoms or surrounding lowlands. Annual temperatures range from pleasant (ca. $72 \mathrm{~F} / 23 \mathrm{C}$ ) to cool on the canyon rims during fall, winter, and early spring to hot as bloody hell (over 105F / 40C) in summer, especially on the canyon floors (e.g. Urique and Batopilas). During winter and early spring, thin blankets of snow can cover the uplands, but they rarely last long.

Most impressive is the wide variety of vegetation found within the differing elevation zones. Given the abundant

* I first became fascinated with, and started gathering information about, Copper Canyon and the Tarahumara Indians during the summer of 2003 while I was doing fieldwork in Chihuahua for a different research project. Then, in the spring of 2004 , led by a local guide named Cristina Hallal, I completed an extensive transect of Barranca del Cobre from Los Mochis, Sinaloa to Creel, Chihuahua. Por chur, that trip afforded me the opportunity to learn considerably more about the region and the Tarahumara culture as I interacted with a wide variety of local residents. I documented my discoveries with field notes and over 300 digital photos. I wish to thank and acknowledge the assistance of Kimberley Smith and Roger and Angela Larson for their help in the fieldwork component of this paper. Additionally, I am deeply indebted to Charles and Sandy Bussing for their valuable feedback and input on an earlier draft of this paper. 


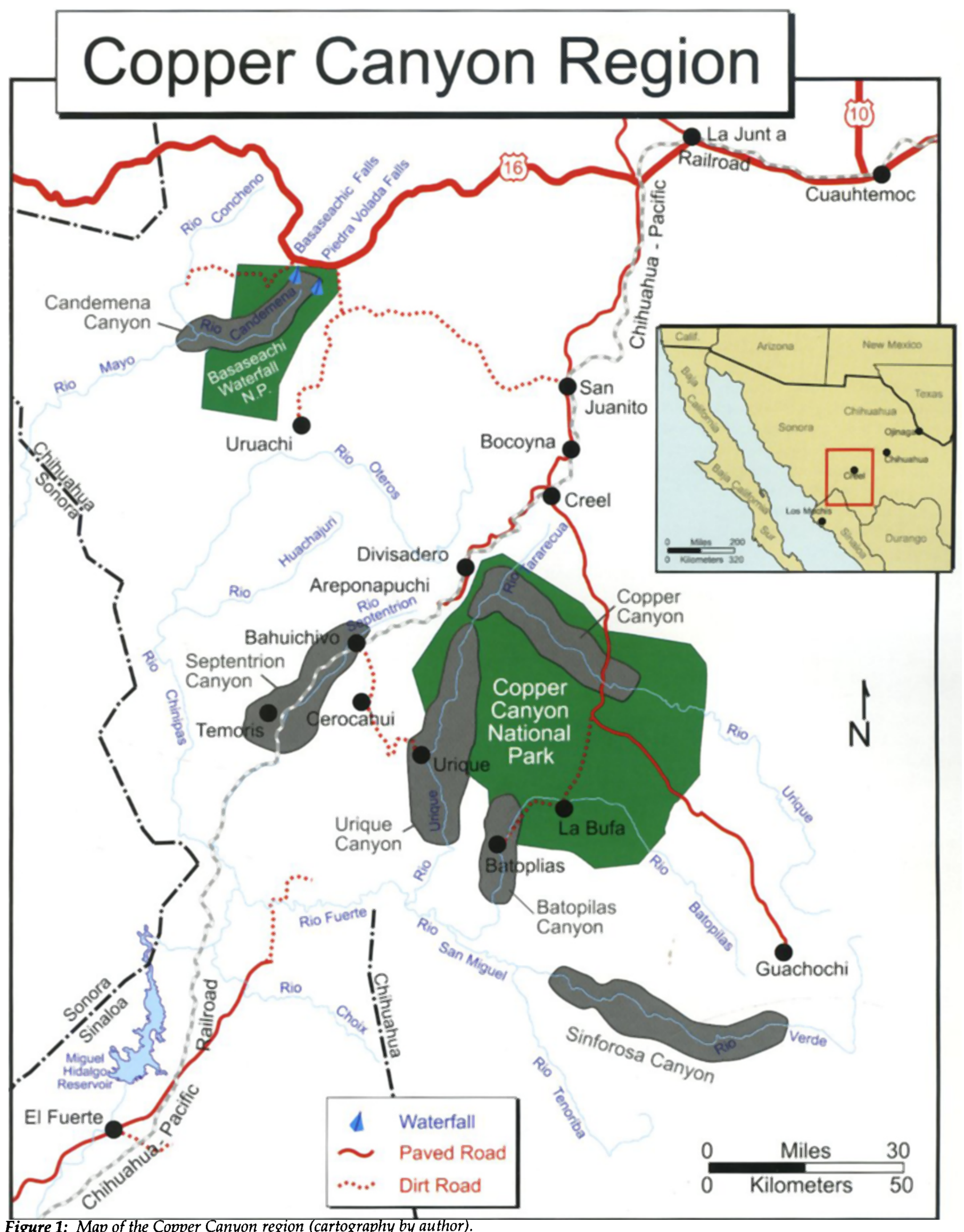

2 FOCUS on Geography Volume 51, Number 3 
moisture and cooler temperatures, Douglas Fir, Mexican white pine, and Ponderosa pine are the dominant tree species found along the canyon rims and uplands. As travelers progress down into the canyons, coniferous species give way to oak, palo verde, and mesquite, in the middle elevations, and a narrow subtropical riparian forest including sycamore in the lowest-lying lands. Throughout the varying vegetation zones is an assortment of xerophytes and succulents including agave, cholla, prickly pear, and yucca that provide an appealing ground cover and stand in stark contrast to taller vegetation.

In 1981 the Mexican Government set aside two large tracts of land as national parks (Parque Natural Barranca del Cobre and Parque Natural Basaseáchic Cascada) to showcase and protect the region's unique natural environment (www.enjoymexico .net). Unfortunately, few financial resources have been invested in environmental education and protection. Noticeably absent are visitor centers and park rangers. The natural landscape alone is enough to make the region a worthy tourist destination on par with Arizona's Grand Canyon. However, the region's natural beauty is only one leg supporting the nascent tourism tripod.

\section{Chihuahua al Pacifico Railroad Chepe}

A second attraction of the region is the Chihuahua - Pacific Railroad. Driven by the desire to create a faster route across North America, American railroad engineer Albert Kinsey Owens was the first to propose building a railroad through Copper Canyon (Los Mochis Chamber of Commerce 2004). In 1861 Owens formed a Mexican-American investment group that two years later began constructing a rail line between Topolobampo, the Mexican port facility on the Gulf of California, and the U.S.-Mexico border at Ojinaga, Chihuahua / Presidio, Texas. In Owens's mind the Copper Canyon railroad was only part of a longer rail line that would extend to Kansas City, Missouri. This transnational rail system would offer an alternative route to the Central Pacific and Union Pacific Transcontinental Railroad traversing the U.S. from Omaha to Sacramento. During the next seventy-seven years, numerous other private investors, including Enrique Creel, owner of the Kansas City, Mexico, Orient Railroad, using financial subsidies from the Mexican Government, attempted to realize Owens's dream. Unfortunately, all failed principally because of the insurmountable cost and tremendous difficulty of laying tracks through Copper Canyon's rugged terrain.

In 1940 the Mexican government nationalized the railroad system and in 1943 began working on those sections that remained undone (mainly through the canyon country). On October 26, 1961 President Aldolfo López Mateos cut the ribbon at the opening of the Chihuahua al Pacifico Railroad providing the first real public transportation route through Sierra Tarahumara. Nicknamed Chepe, the Chihuahua - Pacific Railroad took over 90 years to complete and cost over US $\$ 100$ million (Los Mochis Chamber of Commerce 2004). In the early years of operation the train frequently derailed and passengers were asked to help lever the cars back onto the tracks (Cummings 1998). Moreover, Mexican folk hero Francisco "Pancho" Villa periodically commandeered the train as he and his men stayed one step ahead of the Mexican Army.

The train of today is a far cry from the rustic, dilapidated iron horses featured in numerous Hollywood films. First-class cars are plush with comfortable, reclining seats and central air-conditioning. They provide plenty of room to stretch out and enjoy the views of the canyon through the oversized windows. The dining car even features regional cuisine to satisfy hungry travelers.

Today, the railroad continues to provide a vitally important transportation service for local residents and merchants. Equally important to the local economy, however, Chepe has served to augment tourism in the region. Most of the freight trains operate at night leaving the tracks open for passenger trains during the day.
Each morning at 6:00 am two trains (one at Los Mochis, Sinaloa, the other at Chihuahua, Chihuahua) begin the 13 hour journey meeting at Divisadero to swap crews and refuel. Covering a distance of 390 miles (650 kilometers) between Los Mochis and Chihuahua, the railroad crosses 39 bridges, passes through 86 tunnels (longest tunnel being 4,920 feet/ 1,500 meters), traverses the continental divide three times, and negotiates both a major switchback and dramatic loop. At its highest point the tracks reach an elevation of about 8,200 feet (2,500 meters) above sea level (Figure 2). The engineering feat that went into building the Chihuahua - Pacific Railroad is apparent to even the most casual observer (Figure 3). Throughout much of the journey the train perches precariously on the edge of the canyon's walls. According to local lore, Reader's Digest

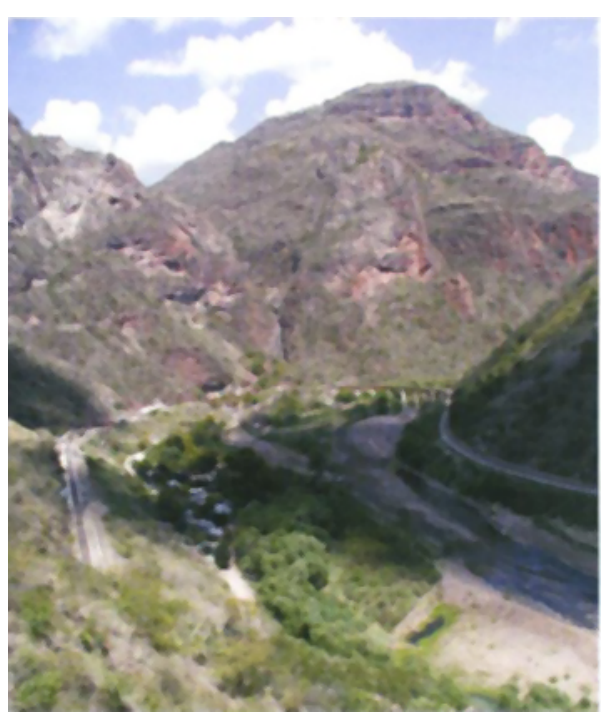

Figure 3: Temoris switchback along the Chepe Railroad (March 2004).

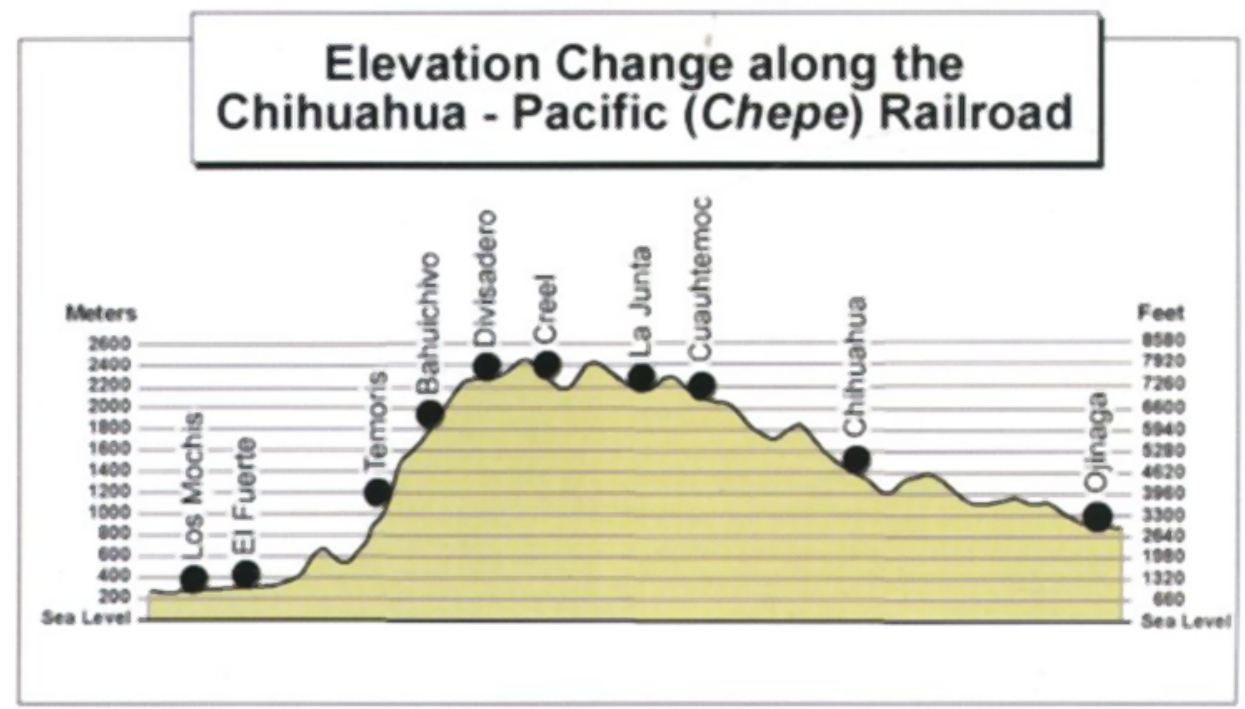

Figure 2: Diagram representing elevation change along the Chihuahua-Pacific Railroad. 
magazine has called the ride through Copper Canyon "the most dramatic train ride in the western hemisphere." Author Joe Cummings (1998) echos this sentiment when he writes that some railroad enthusiasts have gone so far as to declare that Chepe is the world's most scenic railroad line under 1,000 kilometers in length.

Some visitors ride the entire thirteen hour length in one day. Most people, however, utilize the train like a cruise ship stopping each day for "shore excursions". At night they stay in charming local hotels and re-board the train the following day to continue down the line. ${ }^{2}$ Most tour packages start in the western lowlands at either Los Mochis or El Fuerte in the state of Sinaloa and travel upstream toward the highest point along the rail line at Creel, Chihuahua. This route is more appealing because it gives riders the best views of the canyon country during optimal daylight hours. Although nearly all tourists disembark at Creel and return to Los Mochis, the train continues northeast to the Mennonite-dominated area around Cuauhtemoc and on to the city of Chihuahua.

As the elevation increases, the principal population nodes within Copper Canyon that lie along the Chihuahua Pacific Railroad as the elevation increases are El Fuerte, Cerocahui, Divisadero, Areponapuchi, and Creel. El Fuerte, considered the gateway to Copper Canyon, is a popular point of entry to the Chepe railroad. Many tourists arrive by afternoon plane in Los Mochis and take ground transportation to El Fuerte. At 7:40 am the train leaves the El Fuerte depot and a few miles east of town begins its spectacular climb in elevation. El Fuerte's purpose during Spanish colonial times was to act as the seat of government and a regional service center to support the nearby military presidio. The town is home to an impressive 1590's Spanish mission that

2 First-class tickets can be purchased in advance, or at each station depending on space availability. During prime season (March to April and October to November) tickets can be very difficult to acquire. It was interesting to learn that passengers who make multiple stops are only guaranteed a reserved seat for the first leg of their trip. When re-boarding the train, those passengers must find an unoccupied seat for the next leg of their trip. From personal experience recommend enlisting the assistance of a local tour guide to help negotiate the logistics of seating on the train. For more information visit: www.mexperience.com. played an instrumental role in Spain's Repartimento System: The mission's goal was to collectivize the nearby Indians, convert them to Catholicism, and exploit their labor.

The first major stop within the greater Copper Canyon system is Cerocahui. Serving as another point of conversion under Spain's Repartimento System, Cerocahui hosts one of the most impressive Jesuit missions in the entire region. Completed in 1680 by Father Juan Salvatierra, the structure was constructed using local sandstone and features some interesting architectural designs and stain glass windows. Clearly the local population has a skill for stone masonry. A must see at this stop is the view from the Cerro del Gallego overlook of Urique Canyon, the deepest of the Copper Canyon system, (Figure 4). If time, and one's spine/kidneys permit, a day-trip to the bottom of Urique Canyon on an extremely bumpy and winding dirt road provides a fabulous look at how elevation change leads to differences in vegetation type. In a little over 2.5 hours one travels from 7,500 feet $(2,286$ meters) above sea level at the rim to an elevation of 1,590 feet (485 meters) at the river's edge. The trip illustrates the difficulties faced by the local population if they wish to visit the seat of government for Urique Municipio (equivalent to a county in the U.S.). Only two places offer lodging in Cerocahui. Hotel Mission sits in the heart of town, while a few miles away is the very rustic Hotel Paraiso del Oso (translated to

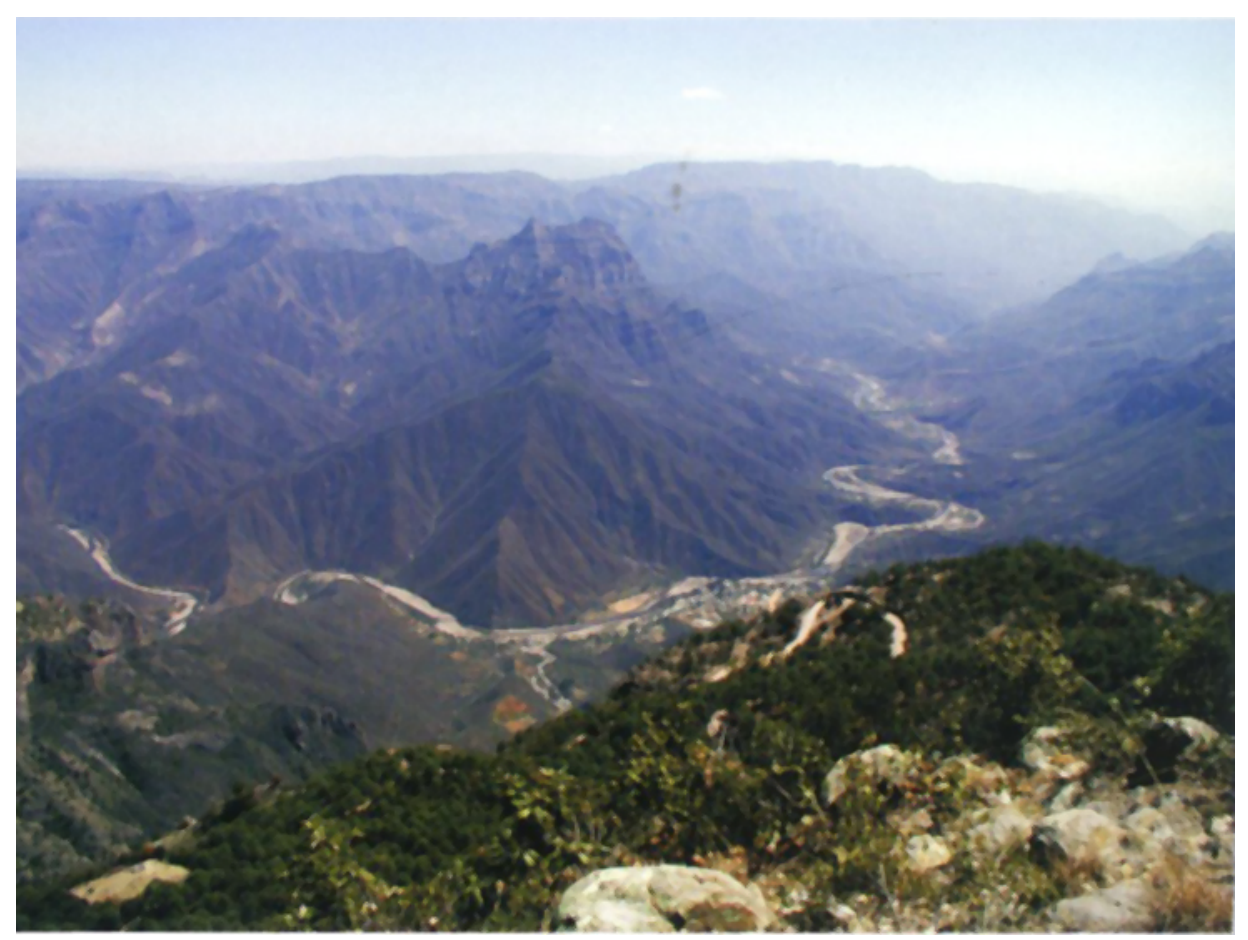

Figure 4: Urique Canyon with town of Urique at bottom center (March 2004). mean Paradise of the Bear because it is named after a local rock formation that looks like Yogi the Bear). The owner, a native of Ohio, offers a wide variety of ecotourism trips that last from a few hours to all day. He also guides multi-day horseback excursions deep into Urique Canyon. Outside influences have been slow to arrive in Cerocahui. All the roads are unpaved, water and sewage services are offered randomly, and public electricity is limited to a few hours each day. Hotel Paraiso del Oso uses kerosene lamps to its guest rooms. In some regards, the semiprimitive nature of Cerocahui adds to tourists' experience by allowing them to get back in touch with nature.

Continuing to climb in elevation, the train's next stop is at Posada Barrancas / Divisadero. Without question this is the most popular tourist disembarking point. The location offers spectacular vistas of three canyons (del Cobre, Urique, and Tararécua) and abundant opportunities for hiking into a nearby canyon or walking along one of the rims through the pine forest. No better place exists to watch the sun both set and rise over Copper Canyon.

Most tourists who stop at Divisadero spend their time at or near the rim of the canyons because, just like Arizona's Grand Canyon, the views are so captivating. At one overlook it is possible to walk right to the edge of an overhang and take in views so steep they could give an experienced sky provide nighttime illumination in each of 
diver vertigo (Figure 5). A hearty few, however, make the 85 mile, ten hour jeep ride down into nearby Batopilas Canyon to the village of Batopilas. The road is so long, bumpy, and filled with pot holes that it takes an entire day to reach the bottom. The multiple stops at scenic overlooks more than make up for the discomfort. Those who venture down typically stay at a local hotel or hostel for two nights and emerge from the canyon on the third day. Batopilas, like Urique, is situated on a narrow flood plain deep at the bottom of its namesake canyon. Both towns were originally founded in the mid-1600s by Spanish explorers and subsequently became productive silver mining towns. At the height of production in the 1890 s Batopilas was one of the richest silver producing regions in the world. Side trips from Batopilas include a half-day trek to the "lost cathedral" where the Black Madonna is on display in the simple chapel. Today, Batopilas has a population just over 500 people and is a tranquil village peppered with modest houses and dilapidated structures left over from the silver mining boom. Despite being an incredibly difficult, bone-jarring journey, a trip to the bottom of one of the canyons is the trip of a lifetime.

Back on top, Areponapuchi is the main bedroom community for local workers. The town offers limited modern services, has a church and school, and is located only minutes away from the tourist zone. Currently, the most impressive hotel in the region - well worth its high tariff - is Hotel Mirador Divisadero Barrancas in

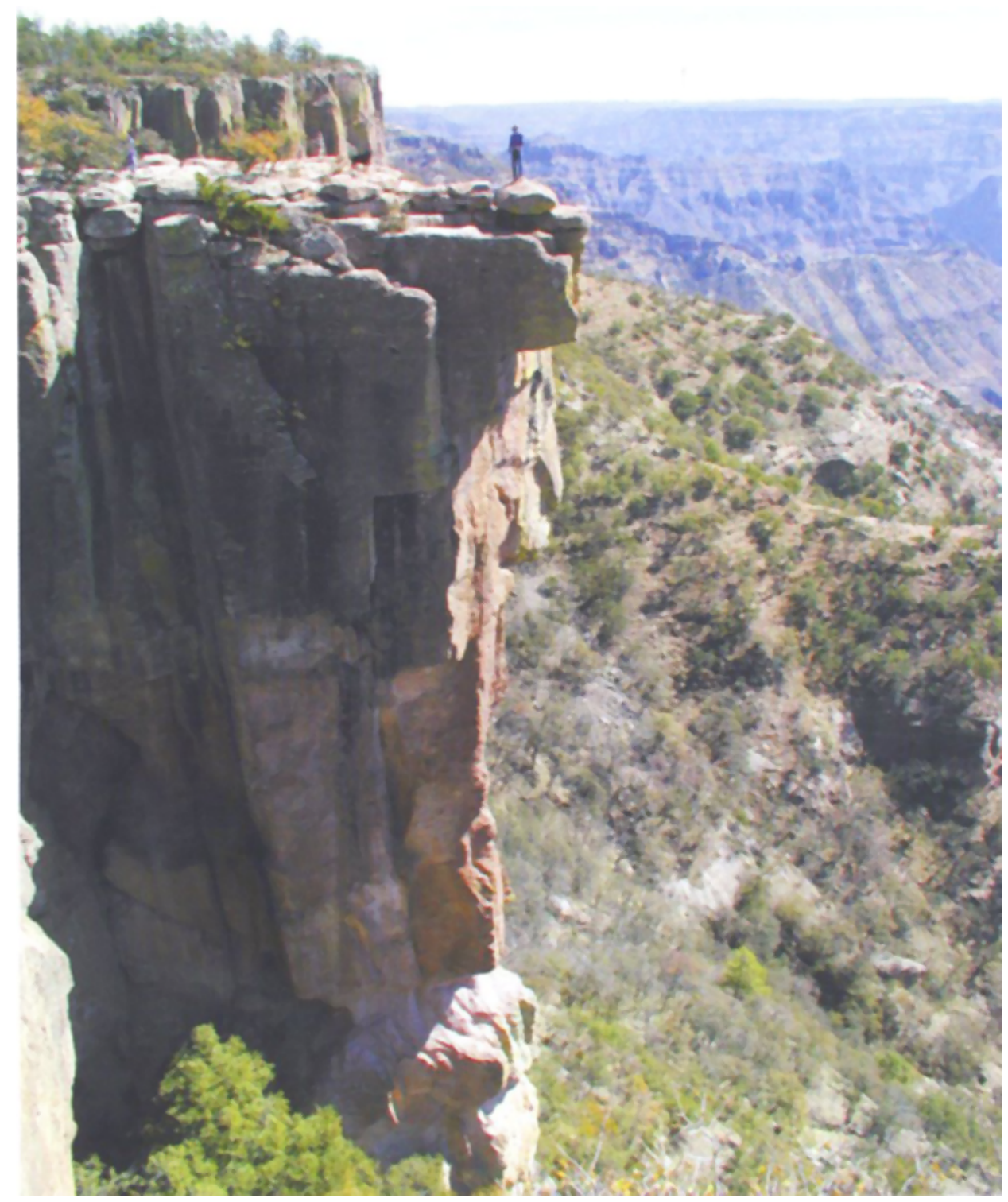

Figure 5: Overlook near Divisadero (March 2004).
Divisadero. Views from the lobby as well as from each individual room are breathtaking. A bit less expensive, but also with spectacular views is Posada Mirador in Areponapuchi (Figure 6). It too has rooms with balconies that overlook Copper Canyon, but it is a bit more rustic. When the rooms at Hotel Mirador and Posada Mirador fill up, the over flow is sent to Mansión Tarahumara, a castle-like structure that is out of scale with the surroundings. Like most of the other businesses around Areponapuchi, it generates most of its revenue during the tourist high seasons of spring and fall.

Because the area around Divisadero is unquestionably the most popular stop along the Chepe rail line and offers the most spectacular views of the Copper Canyon system, the Mexican government has announced plans to expand the tourist infrastructure. Its intentions are to construct a new international airport offering service directly to the U.S. as well as international chain hotels and restaurants that will better accommodate the growing number of foreign tourists attracted to the area.

For most tourists, their final stop along the Chihuahua - Pacific Railroad is Creel. With approximately 4,000 inhabitants, Creel is the region's largest population center. Located at an elevation of 7,660 feet (2,340 meters) above sea level, Creel's main economic base has long been logging and lumber activities (Harner 2003). Although the timber industry continues to provide most of the employment opportunities for local inhabitants, the town acts as the main central place for commercial and governmental activities in the greater Copper Canyon region. As word has spread about Copper Canyon, Creel has also become the principal jumping off place for most multi-day excursions into the back country. Tourists have found that the ideal place to purchase a regional map as well as local souvenirs is at the Tarahumara Artisan Mission run by the local Catholic Church. The merchandise is of good quality, but more importantly, all of the profits are used to help support the local hospital.

Creel appeals to visitors because they can easily soak up the local ambience by ambling down the village streets or sitting on the plaza. It is not uncommon, for example, to see Tarahumara men in their traditional dress cross paths with dreadlock-clad trust-fund dependents or grungy, middle-aged backpackers returning from a week in the wilderness. 
Visitors may be fortunate enough to encounter a group of Tarahumara women sitting in front of the Catholic Church. Or one might see a high performance sports car parked in front of the same structure (Figure 7). Such examples of interesting juxtapositions and clashes of culture make Creel an exceptionally interesting place to visit.

Clearly the spectacular scenery combined with the engineering feat of the Chepe Railroad make Copper Canyon a worthy tourist attraction. However, the rich culture of the Tarahumara Indians also adds to the enjoyment of the region.

\section{Tarahumara (Rarámuri) Indians}

Compared to the Chihuahua - Pacific Railroad, the Tarahumara Indians have left a softer and more subtle patina on the natural landscape. Yet, the trained eye will detect abundant evidence of their nearly ubiquitous presence within the Copper Canyon region. Referring to themselves as Raramuri, "the people of the swift running feet" or "the runners", the Tarahumara are believed to be descendants of the Aztecs, who originally settled in the grasslands of Mexico's central plateau. As Spanish influences slowly marched north, the Tarahumara gradually retreated into the rugged uplands of the western Sierra Madre as a way to avoid assimilation (Pennington 1963). For over 400 years they have inhabited the steep slopes and isolated valleys throughout the region and continued to resist adopting Mestizo cultural traditions (Marak 2003).

Today approximately 60,000 Tarahumara reside throughout the canyon country, making them Mexico's largest

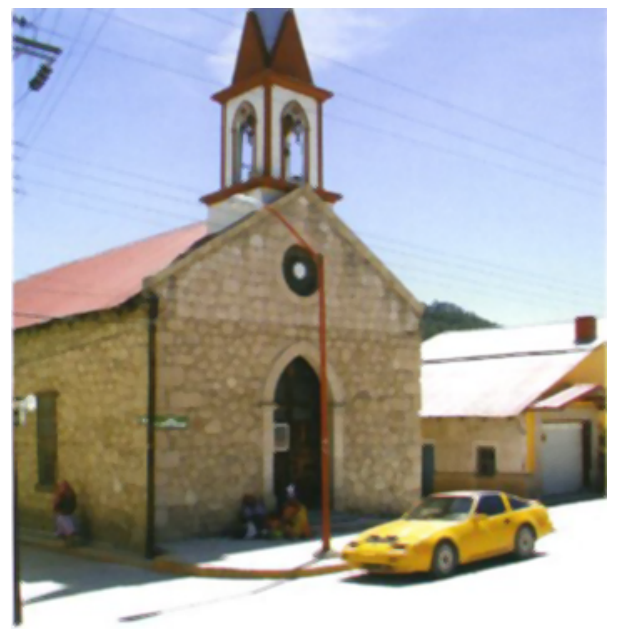

Figure 7: Catholic church in Creel with Tarahumara women and a sports car parked in front (March 2004).

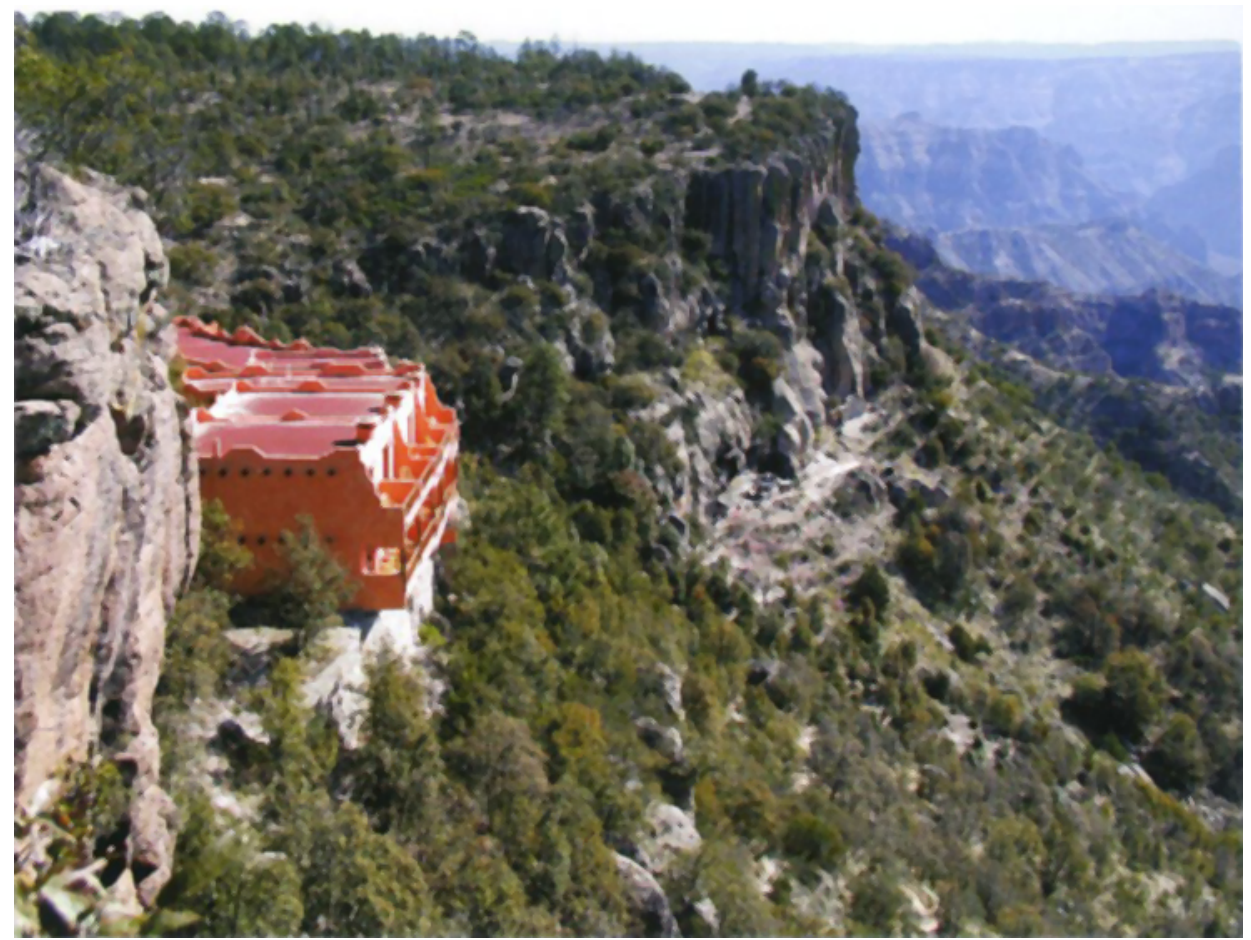

Figure 6: Rooms at hotel Posada Mirador with spectacular view hanging over canyon wall near Areponapuchi. Notice the Tarahumara houses due right of the hotel (March 2004).

indigenous group north of Mexico City. Living in small scattered settlements or individual homesteads often perched on a rock outcropping or on the side of a steep hill, the Tarahumara lead a largely reclusive lifestyle. ${ }^{3}$ They have adapted remarkably well to the hot, dry summers and cool winters. Some Tarahumara live in modern dwellings, but most traditional Tarahumara still live in simple stone huts or under rock overhangs with crude walls built for privacy and protection from the elements (Figure 8). The location of household dwellings changes with the

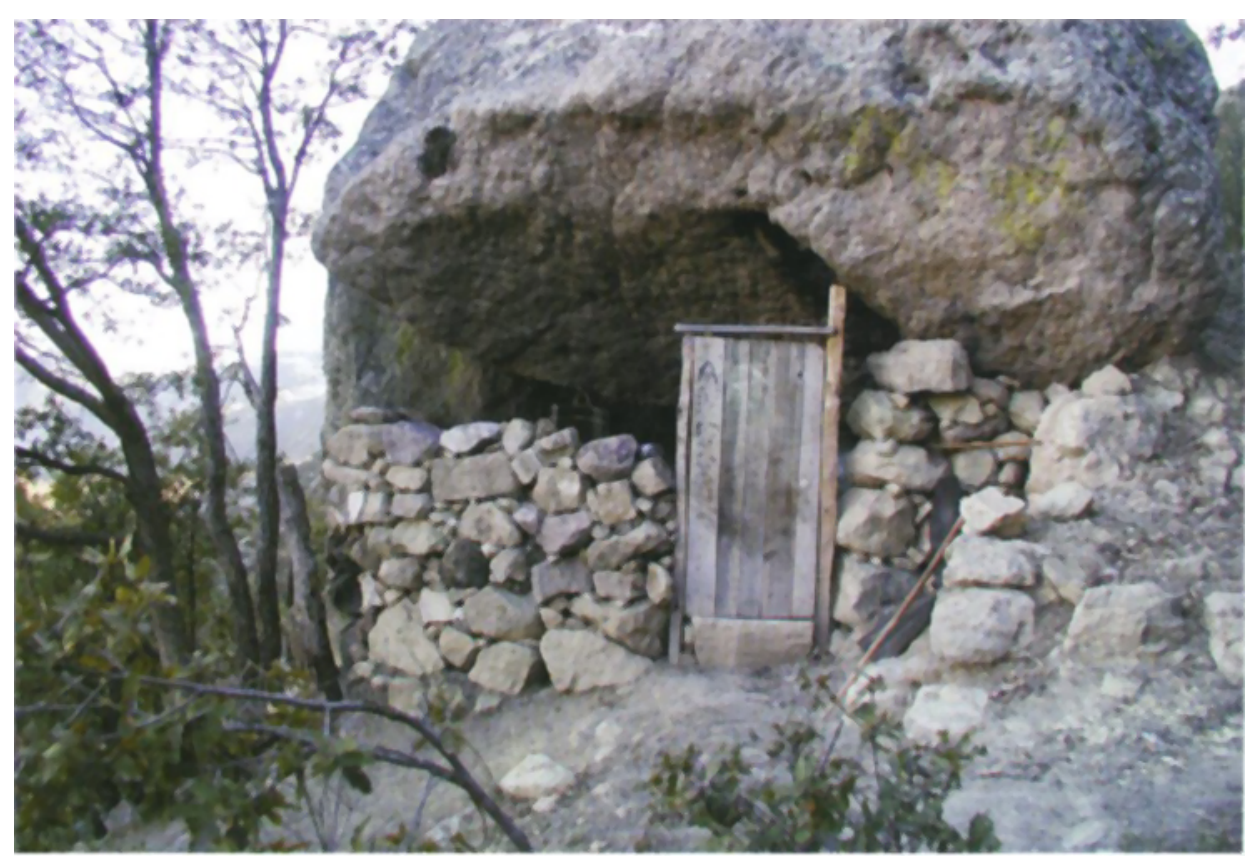

Figure 8: Typical Tarahumara house (March 2004).

3 Most Tarahumara appear to prefer living apart from the "outside" world thriving on subsistence agriculture and maintaining their cultural traditions. Some, however, have embraced the cash economy and can be found living among Mestizos in cities like Cuauhtemoc and Chihuahua City. 
seasons. During summer when the heat at the bottom of the canyons is intolerable, the Tarahumara move higher up along the canyon rim. In winter when the temperatures drop, they move to the warmer lowlands or canyon bottoms. Regardless of location, their houses have a distinctive smoke varnish that covers the surrounding rocks and marks where the cooking/heating fire is located (Figure 9).

The Tarahumara have been able to resist assimilation due to a largely subsistence, self-sufficient lifestyle. Joe Cummings (1998) writes that Tarahumara agricultural practices are considered one of the most complex and productive indigenous agricultural systems in the new world. In addition to raising cattle, sheep, goats, and pigs, a variety of subsistence crops are grown on oversized benches or terraces carved into the steep slopes (Figure 10). Maize (corn) is their principal crop and constitutes a major component of their diet. Each spring at least six different types of cornincluding red, white, blue and yellow are sown. Some of the corn is used to make tesgüino, a deceptively potent alcoholic corn beverage similar to beer, but thicker in consistency. Given the importance of corn to their diet and customs, the Tarahumara are some of the most outspoken people arguing against the introduction of hybrid corn from the United States being imported into Mexico (The Economist 2004). They are justifiably concerned at what impact the genetically engineered corn may have on their own crops and lifestyle. Other important subsistence crops grown by the Tarahumara include squash, beans, potatoes, and an assortment of fruit (especially apples and peaches). One of the easiest ways to identify and locate an isolated Tarahumara homestead is to look for the blooming fruit trees in springtime (Figure 11).

Having lived in isolation for so long, both by choice and because of the environment in which they live, little of the outside world has penetrated the far reaching corners of the Sierra Tarahumara. Often the visitor finds a woman wearing the traditional, brightly colored skirt with loose blouse, a wool belt (pukera), and her head covered with a shawl (Figure 12). Most men, by comparison, dress in a more modern attire of long pants and collared shirt. However, it is possible to encounter a man dressed in traditional clothing with a headband (kowera), an oversized white shirt, loose shorts, and huarache-type sandals (zaraza) (Figure 13). Be aware that not all men clad in such traditional attire

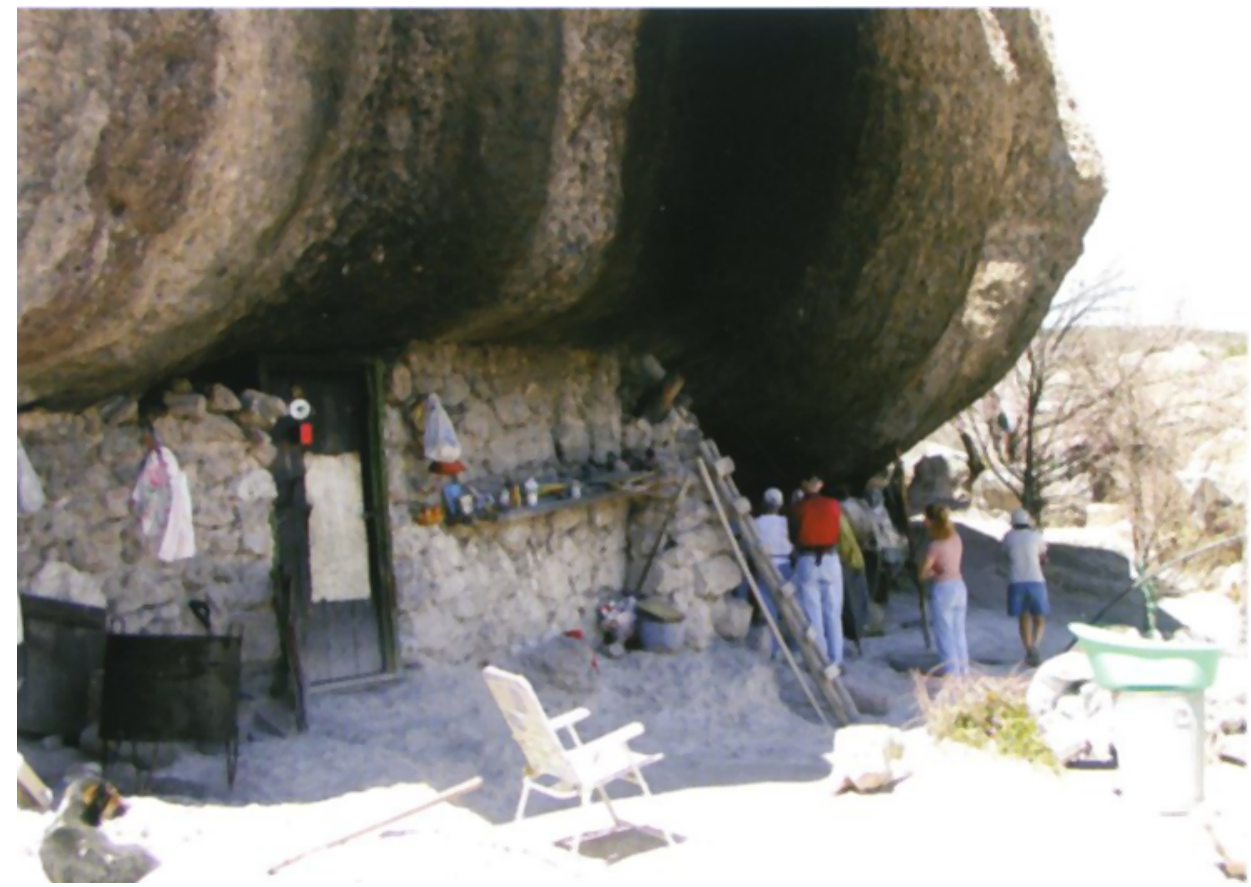

Figure 9: Tarahumara house with smoke varnish covering rock overhang (March 2004).

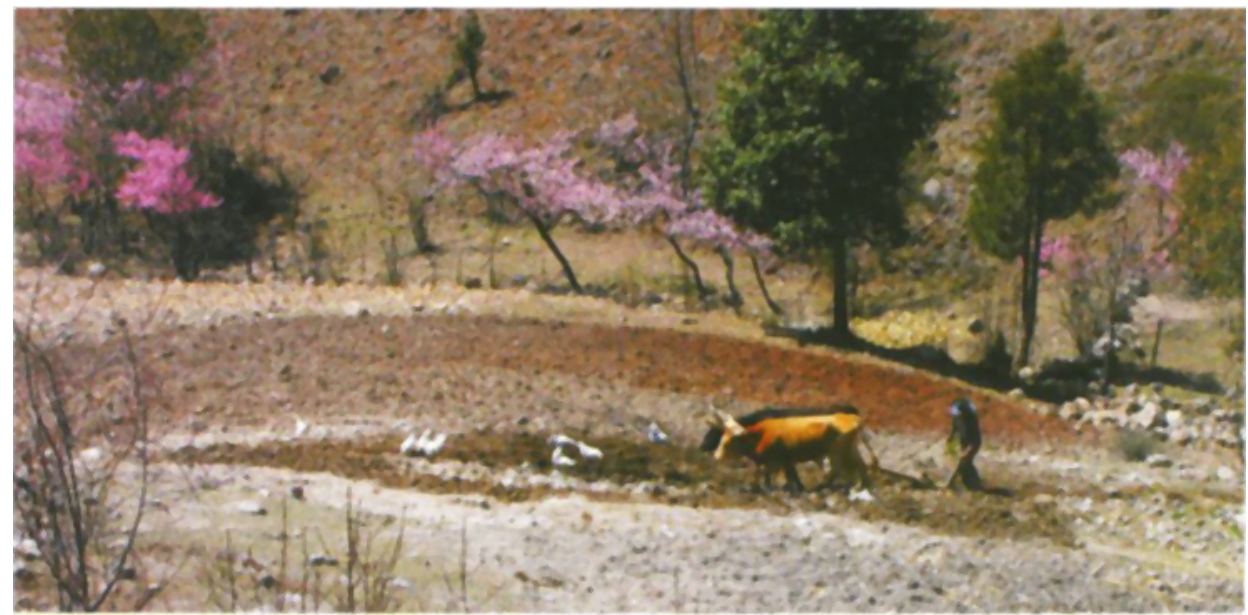

Figure 10: Tarahumara man plowing field with oxen (March 2004).

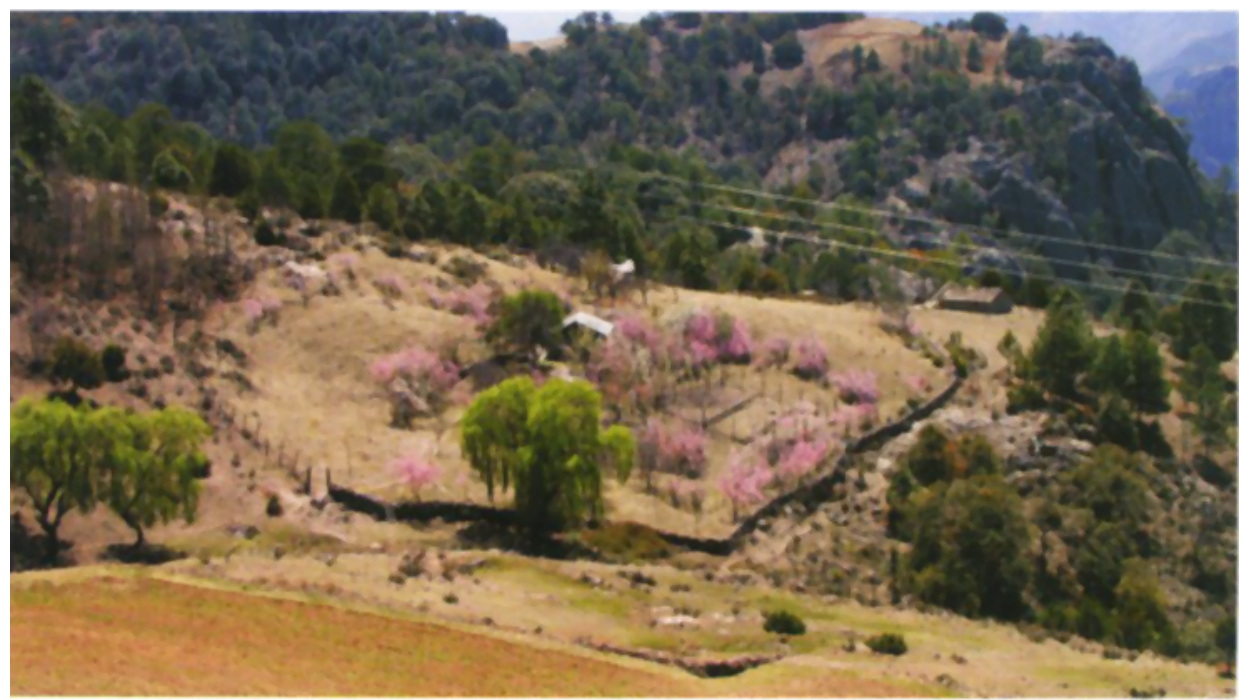

Figure 11: Typical Tarahumara homestead surrounded by fruit trees in bloom (March 2004). 
will permit outsiders to take their photo.

The Tarahumara are famous for being some of the best long-distance runners in the world (Mares 1999). At the annual holy week celebrations, different categories of long distance running events based on age and gender are held. Some men run for 40 miles (65 kilometers) up and down hill slopes and across flood plains throughout the canyons during a six to eight hour race. Others compete in an even longer distance race (called rarjiparo) where a team of two to twelve men kick a 4 inch (10 centimeter) wooden ball over a wide variety of terrain for two days without stopping.

One of the most interesting times of year to visit Copper Canyon and explore the Tarahumara culture is just prior to and during holy week. In the weeks leading up to Easter it is common to hear drums echoing through the canyons as local Tarahumara practice their parts in upcoming religious ceremonies. During holy week each village re-enacts the last days of Christ with a strong Tarahumara religious twist added. For example, one village is reported to celebrate holy week by dressing up a straw replica of Judas with an oversized penis and parading it around. Eventually the effigy is stabbed and burned on holy Saturday morning (Sée 1989). Evidence of religious syncretism not only in religious celebrations, but also in the mission churches, is abundant (Figure 14).

According to Barney Burns (1996), the origins of Tarahumara arts and crafts remains a mystery. However, as a way to

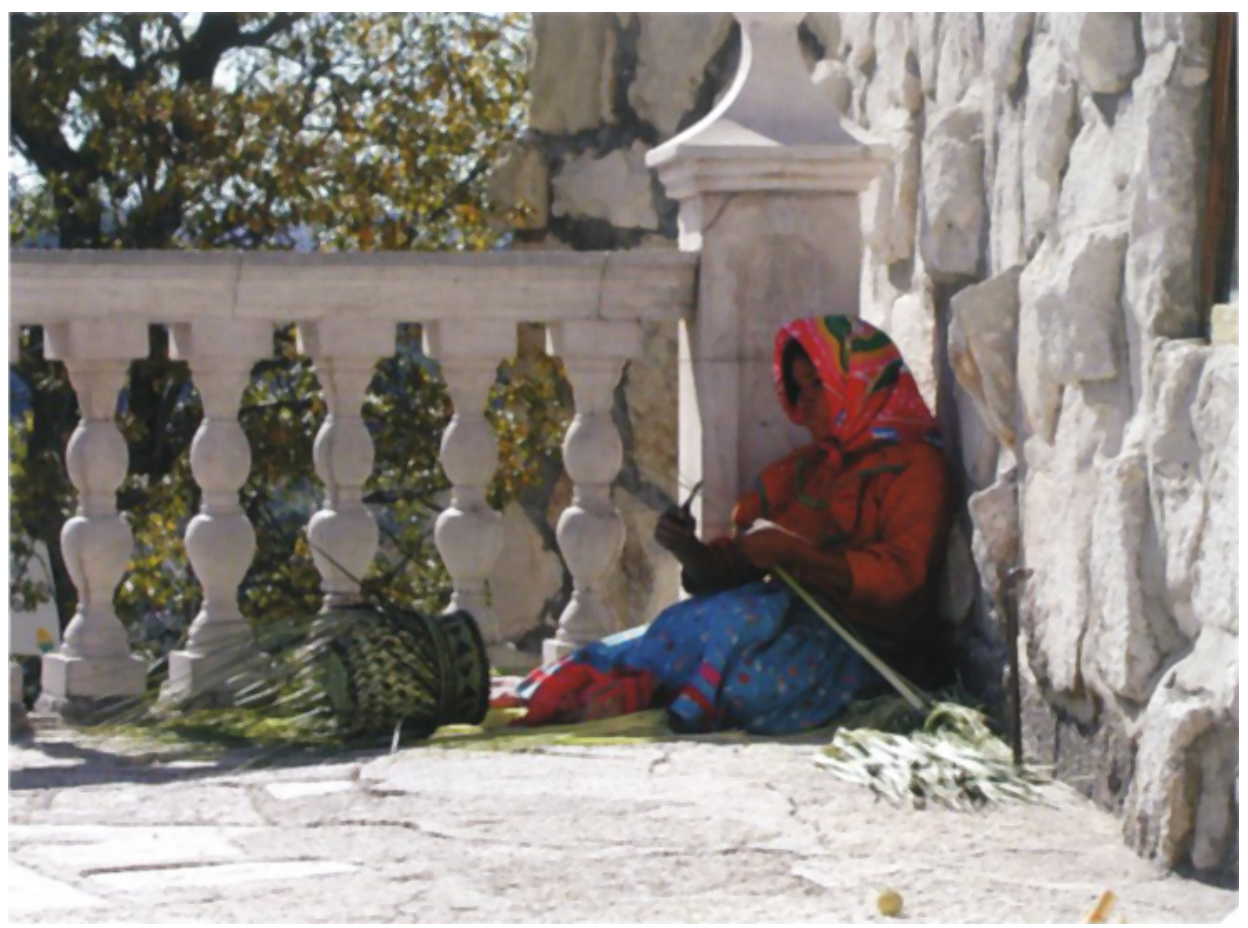

Figure 12: Tarahumara young woman weaving a basket in shade of hotel (March 2004).

supplement their subsistence livelihood, many of the women, both wives and daughters, in Tarahumara households make and sell baskets to tourists (Figure 15). The most common basket type is woven from strips of yucca leaves. The quality is remarkably good; and some of the colors, shapes, and designs are truly impressive. A few women make baskets woven from pine needles. These baskets are typically smaller in size, take considerably longer to make, and are therefore more expensive. Finding a woman willing to sell a hand-woven basket is not difficult. One might be driving along an isolated road and from out of nowhere a lady appears with a handful of baskets. Or, a hiker might be in what appears to be an isolated part of the canyon and as $s /$ he rounds a corner there sits a young woman weaving baskets ready to sell to tourists (Figure 16). Their ubiquitous presence is further indication of the

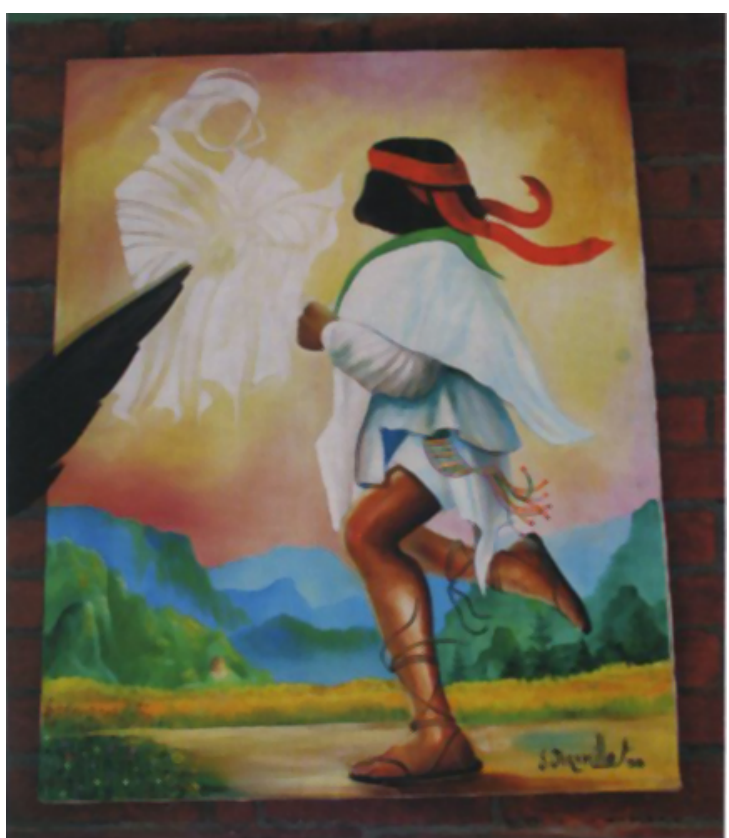

Figure 13: Public painting showing the traditional dress for Tarahumara men (March 2004).

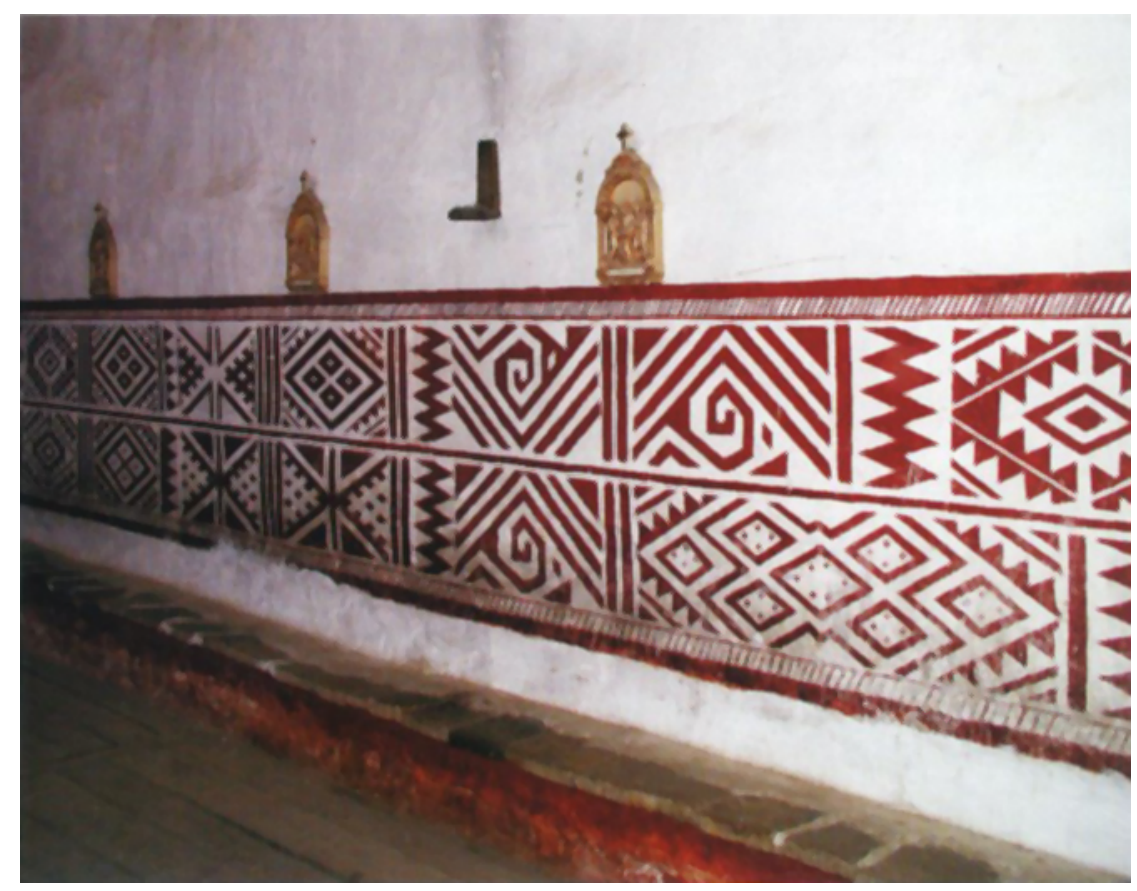

Figure 14: Religious syncretism inside a Tarahumara Catholic church (March 2004). 


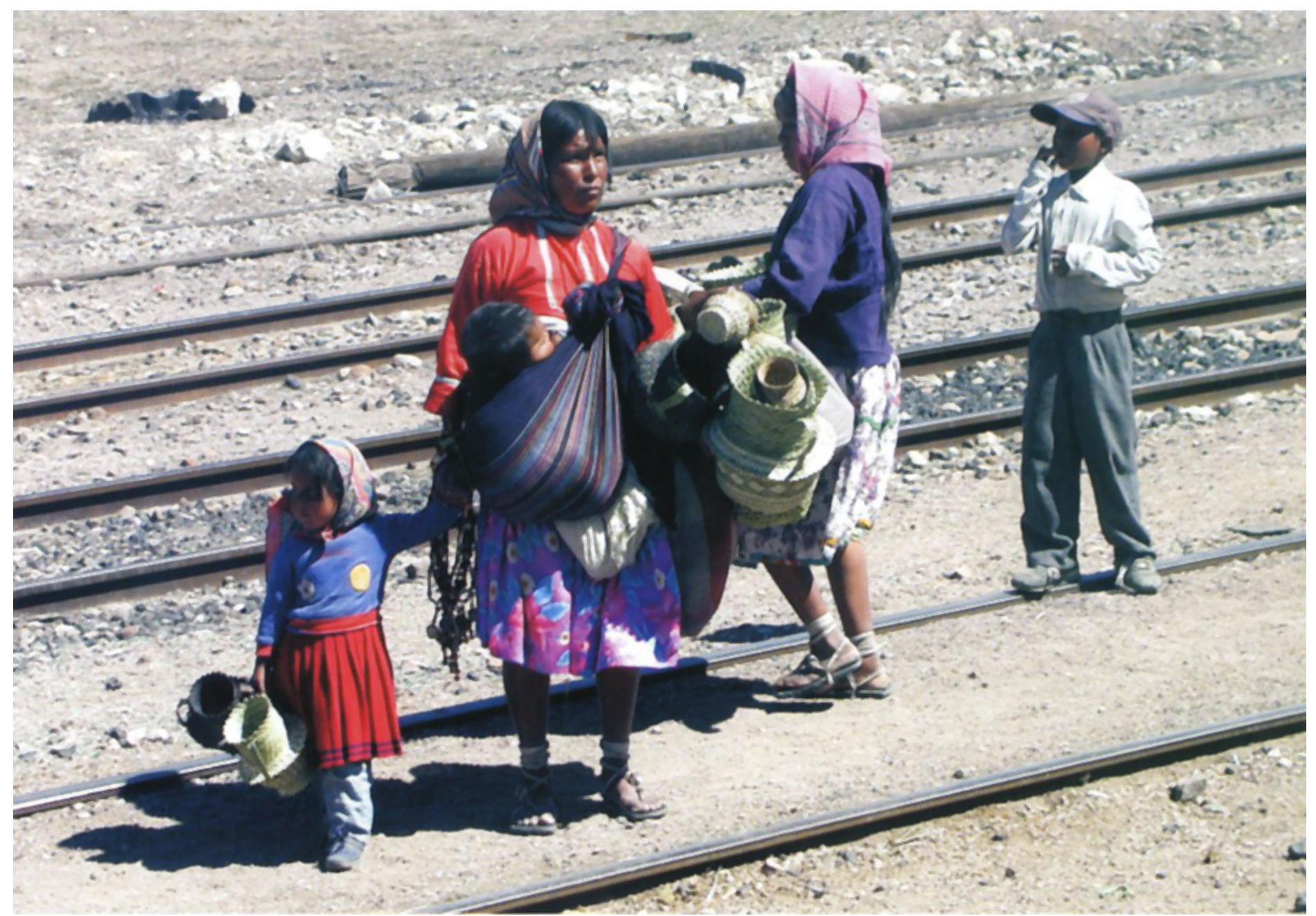

Figure 15: Tarahumara woman selling baskets on train tracks (March 2004).

dispersed and isolated nature of the Tarahumara homesteads.

Many challenges face the Tarahumara as the outside world encroaches upon them. Outside cultural influences are impacting the Tarahumara youth. According to Greg Bloom (2003), an increasing number of youth yearn for a more modern lifestyle with conveniences such as televisions, radios, and cell phones. Living in a dry and harsh environment contributes to two other ongoing challenges namely unpredictable harvests and chronic malnutrition. Finally, the rugged topography and geographic isolation have led to an increase in clandestine smuggling activities especially of narcotics and of illegal timber harvesting Mexican government officials have a difficult enough time dealing with these issues in more accessible locations. They have deployed numerous army troops to the remote areas to help fight the drug trafficking problem. The government, however, is not wholly benign. The latest threat to the traditional Tarahumara way of life comes from various proposals to expand logging in the western Sierra Madre (Bloom 2003). Increased logging could lead to severe environmental degradation and a loss of natural habitat. To counteract this proposal and help diversify the local tourism economy, local Tarahumara with financial support from the Mexican government are trying to offer grassroots ecotourism packages. To date, they have established an ecological park at Cascada de Cusarare (Cusarare Falls) (Figure 17). Profits from the venture are reported to help sustain the local environment for future generations. Other local residents offer tours to bird enthusiasts.

\section{Conclusion}

On October 26, 1979 Arizona's Grand Canyon was designated as an UNESCO World Heritage Site because of its exceptional natural beauty, evolutionary history, and ongoing geological processes (UNESCO 2008). Given its obvious grandeur and spectacular scenery, it is little wonder that the nearly five million people
(NPS 2008) who are drawn annually to the U.S.'s most popular national park are aweinspired and impressed. As Edward Abbey once wrote:

"Those who love it call it the canyon. THE canyon. As if there were no other topographic feature on the face of the Earth". (Abbey 1991; p144)

As Grand Canyon National Park becomes increasingly crowded, congested, and polluted, perhaps Mexico's Copper Canyon will serve as an alternative destination for tourists seeking similar qualities.

The Barranca del Cobre system covers a larger spatial area and is deeper in places than the Grand Canyon. Moreover, much like the Grand Canyon, Copper Canyon offers an excellent example of thousands of years of arid-land erosion that has cut through multiple life zones and is home to a wide variety of rare, endemic species. Plus, with only 60,000 visitors annually (Chihuahua State Tourism Office 2008), Barranca del Cobre still offers the 


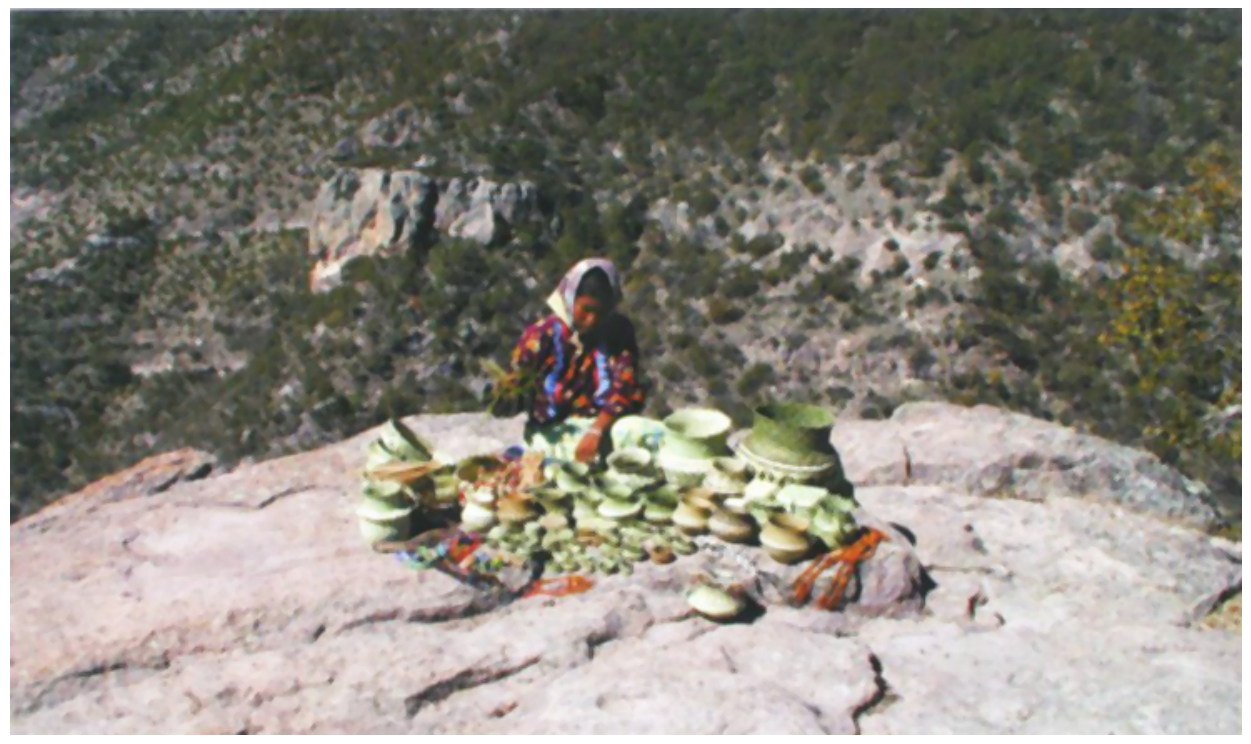

Figure 16: Tarahumara girl weaving baskets on the edge of a canyon cliff (March 2004).

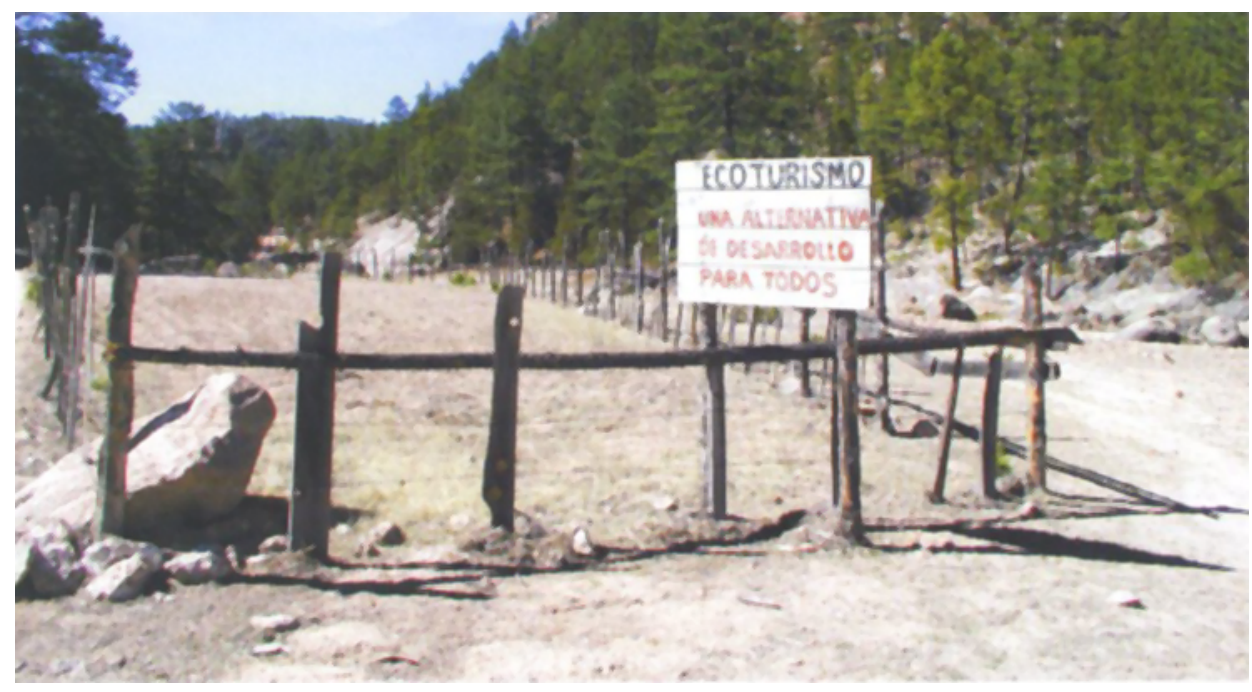

Figure 17: Photo of ecotourism sign near Cusarare Falls. The sign reads "Ecotourism. An alternative development for everyone" (March 2004).

opportunity for breath-taking vistas and geological marvels without the crowds.

Copper Canyon offers two opportunities that Arizona's Grand Canyon does not. First, a ride through the canyon on the Chihuahua-Pacific Railroad not only affords visitors a completely different perspective, but also gives them a first-hand look at an engineering marvel. Second, visitors to Barranca del Cobre will have the opportunity to witness and interact with a culture group that has lived in relative isolation and has largely resisted assimilating with the outside world for the better part of four centuries.

Each of these three elements alone is enough to attract large numbers of visitors annually and support a healthy local tourist economy. When combined, the spectacular natural beauty, remarkable human engineering, and rich, indigenous cultural traditions help create a truly exceptional place. Certainly, the Mexican government realizes the region's potential and is beginning to expand the local tourist infrastructure. These enhancements will undoubtedly lead to significant growth in the number of visitors arriving annually, but they also will bring about dramatic and irreversible changes to the place.

\section{References:}

Abbey, Edward. 1991. Down the River. New York: Penguin Group.

Anonymous. 2006. Sierra Tarahumara: Barrancas Del Cobre. International Map Co. El Paso, TX. (map available at wrandongitudebooks.com).

Bloom, Greg. 2003. The Sierra Tarahumara:
Indigenous Peoples, Species, and Forests Struggle to Survive. Frontera NorteSur online (fnsnews@nmsu.edu); received 29 April 2003.

Burns, Barney T. 1996. Evolving Tarahumara Arts and Crafts. Journal of the Southwest 38(4):463-473.

Chihuahua State Tourism Office. 2008 URL: www.chihuahua,gov.mx

Cummings, Joe. 1998. Northern Mexico Handbook, $2 d$ ed. Chico, CA: Moon Publications, Inc.

Harner, John P. 2003. Learning in Mexico, Learning From Mexico: A Field Class to Chihuahua. Pacifica, The Association of Pacific Coast Geographers Spring, p.1, 8-12.

Los Mochis Chamber of Commerce. 2004. Brief History of the Chihuahua Al Pacifico Railroad. Los Mochis: Printed by Chamber of Commerce.

Marak, Andrae M. 2003. The Failed Assimilation of the Tarahumara in Postrevolutionary Mexico. Journal of the Southwest 45(3):411-436.

Mares, Albino. 1999. Hit and Run: The Game Ra'Chuela. Natural History 108(7):50.

NPS, National Park Service. 2008. URL: www.nps.gov/grca/parkmgmt/index. htm (last visited 6 June 2008).

Pennington, Campbell W. 1963. The Tarahumar of Mexico: Their Environment and Material Culture. Salt Lake City, UT: University of Utah Press.

Sée, Melville. 1989. Among the Tarahumara: Semana Santa in the Remote Sierra Madre. American West 26(2):58-65.

The Economist. 2004. From Corn Wars to Corn Laws: A National Nervous Breakdown Over Maize. 25 September, p.50.

UNESCO, United Nations Educational, Scientific and Cultural Organization. 2008. "World Heritage List" URL: http://whc.unesco.org/en/list (last visited 6 June 2008).

www.enjoymexico.net. 2008. "Barrancas Del Cobre: Travel and Tours I $n$ f orm a $t$ i o n " UR L : www.enjoymexico.net./barrancas-delcobres-mexico.php (last visited 6 June 2008).

www.mexicoscoppercanyon.com. 2008. "Copper Canyon Information" URL: www.mexicoscoppercanyon.com/cany oninfo.htm (last visited 6 June 2008).

www.mexperience.com. 2008. "Copper Canyon and Train Journey, Mexico." URL: www.mexperience.com/guide/ outdoors/copper_canyon.htm. (last visited 16 January 2008). 